\title{
DAYS TO RECOLLECT
}

Do you recall

That day in Fall

When we walked towards Saint Alban's Head,

On thistledown that summer had shed,

Or must I remind you?

Winged thistle-seeds which hitherto

Had lain as none were there, or few,

But rose at the brush of your petticoat-seam

(As ghosts might rise of the recent dead),

And sailed on the breeze in a nebulous stream

Like a comet's tail behind you:

You don't recall

That day in Fall?

Then do you remember

That sad November

When you left me never to see me more, And looked quite other than theretofore,

As if it could not be you?

And lay by the window whence you had gazed

So many times when blamed or praised, Morning or noon, through years and years, Accepting the gifts that Fortune bore, Sharing, enduring, joys, hopes, fears!

Well: I never more did see you. -

Say you remember

That sad November! 